\title{
T-Lymphocyte Activation Increases Hypothalamic and Amygdaloid Expression of CRH mRNA and Emotional Reactivity to Novelty
}

\author{
Alexander W. Kusnecov, ${ }^{1}$ Rumei Liang, ${ }^{2}$ and Galina Shurin ${ }^{3}$ \\ 1Department of Psychology, Rutgers University, New Brunswick, New Jersey 08901, and Departments of 2Pathology and \\ 3Surgery, University of Pittsburgh School of Medicine, University of Pittsburgh, Pittsburgh, Pennsylvania 15238
}

Stimulation of T-cells with staphylococcal enterotoxin B (SEB) significantly elevates interleukin-2 (IL-2) and contemporaneous activation of the hypothalamic-pituitary-adrenal (HPA) axis and $c$-fos in the paraventricular nucleus (PVN) of BALB/cByJ mice. Such neural signaling may promote cognitive and emotional adaptation before or during infectious illness. Because corticotropin-releasing hormone $(\mathrm{CRH})$ is an anxiogenic neuropeptide that may mediate the stressor-like effects of immunological stimuli, we measured neuronal $\mathrm{CRH}$ mRNA alterations in mice challenged with SEB. Increased $\mathrm{CRH}$ mRNA levels were observed in the PVN and central nucleus of the amygdala (ceA) 4-6 hr after SEB administration. This was associated with plasma ACTH increases, which could be abrogated by the systemic administration of anti-CRH antiserum. Additional experiments did not support a role for IL-2 or prostaglandin synthesis in activating the HPA axis. Behavioral experiments testing for conditioned taste aversion did not confirm that SEB challenge promotes malaise. However, consistent with the notion that central $\mathrm{CRH}$ alterations induced by SEB may affect emotionality (e.g., fear), SEB challenge augmented appetitive neophobia in a context-dependent manner, being marked in a novel and stressful environment. It is hypothesized that immunological stimuli generate a cascade of events that solicit integrative neural processes involved in emotional behavior. As such, these data support the contention that affective illness may be influenced by immunological processes and the production of cytokines and are consistent with other evidence demonstrating that autoimmune reactivity is associated with enhanced emotionality.

Key words: T-lymphocytes; corticotropin-releasing hormone; staphylococcal enterotoxin B; adrenocorticotropic hormone; psychoneuroimmunology; emotion; neophobia; interleukin-2; cytokines; prostaglandins; stress; amygdala; hypothalamus
The nervous and immune systems share a mutually interactive relationship that promotes various forms of physiological and behavioral adaptations in the face of pathogenic challenges (Besedovsky and Del Rey, 1996). There is also evidence that neural and behavioral adjustments to infection and/or cytokine treatment may impose additional and potentially subversive demands on neurochemical resources supporting emotional and cognitive functions (Anisman and Zacharko, 1992; Dunn, 1993; Maier and Watkins, 1998). Therefore, immunologically provoked behavioral repertoires such as anorexia, lethargy, and sleep (Kent et al., 1992; Plata-Salaman, 1996; Maier and Watkins, 1998) may occur at some expense to psychological well being, as further suggested by neurochemical mapping studies identifying immune activation as a stressor that engages neural substrates of emotional reactivity (Anisman et al., 1993; Dunn, 1993; Haas and Schauenstein, 1997). In particular, amygdaloid and hypothalamic neurons synthesizing the anxiogenic neuropeptide, corticotropinreleasing hormone (CRH; Dunn and Berridge, 1990; Heilig et al., 1994), are highly responsive to immunological stimuli (Berkenbosch et al., 1987; Sapolsky et al., 1987; Laflamme et al., 1997),

Received Nov. 18, 1998; revised Feb. 23, 1999; accepted Feb. 26, 1999.

This work was supported by United States Public Health Service Grant MH51051 to A.W.K. G.S. was supported by Behavioral Immunology Training Grant MH18903. We are grateful to Dr. Audrey Seasholtz (University of Michigan, Ann Arbor) and Dr. Cynthia Watson (Laboratory of Immunology, National Institute for Allergy and Infectious Diseases) for providing cDNA encoding murine corticotropin-releasing hormone and interleukin-2.

Correspondence should be addressed to Dr. Alexander W. Kusnecov, Department of Psychology, Biopsychology and Behavioral Neuroscience Program, Rutgers University, 152 Frelinghuysen Road, Piscataway, NJ 08855.

Copyright (C) 1999 Society for Neuroscience $0270-6474 / 99 / 194533-11 \$ 05.00 / 0$ raising the possibility that fundamental alterations in mood and cognition may occur independently of or before more obvious signs of infectious illness. In apparent support of this, immunological cytokines [e.g., interleukin-1 (IL-1)] and the bacterial endotoxin lipopolysaccharide (LPS) have been shown to reduce exploratory behavior in novel or precarious test environments (Spadaro and Dunn, 1990a; Dunn et al., 1991; Montkowski et al., 1997; Connor et al., 1998; Lacosta et al., 1998), in some cases dependent on central CRH receptors (Dunn et al., 1991) but in others influenced by depressive illness-like effects on locomotion (Montkowski et al., 1997). Additionally, mice progressing into developmentally regulated stages of autoimmune reactivity display increased emotionality (Schrott and Crnic, 1996, 1998). Finally, clinical trials designed to boost T-cell immunodeficiencies with cytokine immunotherapy (e.g., IL-2) have reported neuropsychiatric and neuropsychological side effects (Walker et al., 1996, 1997), and immune responses have been implicated in the etiology or exacerbation of affective disorders (Maes, 1995).

Circumvention of undesirable CNS effects by otherwise beneficial immunotherapeutic protocols, as well as immune disorders, requires greater preclinical knowledge of the neurobehavioral impact of immunological factors. Although efforts to achieve this goal have embraced models encompassing the full extent of the immunological repertoire, less attention has been given to the combined neural and behavioral impact of T-lymphocytes, which orchestrate most immune responses (London et al., 1998). A prominent model of T-cell activation in vivo uses the staphylococcal enterotoxins (SEs) produced by the Gram-positive bacteria Staphylococcus aureus, a major cause of food poisoning (John- 
son et al., 1991; Kotzin et al., 1993; Marrack et al., 1993). One of the best characterized is staphylococcal enterotoxin B (SEB), which in vivo elicits major production of interleukin-2 (IL-2), interferon- $\gamma($ IFN- $\gamma)$, and tumor necrosis factor (TNF) by CD4 ${ }^{+}$ $\mathrm{T}$-cells, with peak concentrations of these cytokines occurring by $2 \mathrm{hr}$ after challenge and returning to baseline levels several hours later (Bette et al., 1993; Gonzalo et al., 1993, 1994; Florquin et al., 1994; Litton et al., 1994). Challenge with SEB dose-dependently activates the hypothalamic-pituitary-adrenal (HPA) axis, with coincident immediate early gene induction in the paraventricular nucleus (PVN) of the hypothalamus (Shurin et al., 1997). Moreover, T-cell-derived IL-2 production follows closely the time course of plasma corticosterone elevations after challenge with not only SEB but also other SEs (Shurin et al., 1997).

Because CRH release from the PVN serves as the primary source of secretagogue action on pituitary corticotrophic cells (Owens and Nemeroff, 1991; Smith et al., 1998), it was hypothesized that central CRH mediated the effects of T-cell reactivity on HPA activation. The results of the present investigation revealed that increased adrenocorticotropic hormone $(\mathrm{ACTH})$ production after T-cell activation with SEB relied on CRH release, but not on circulating IL-2 or prostaglandin synthesis. Furthermore, SEB challenge enhanced central CRH mRNA levels, which was not associated with illness behavior but was associated with appetitive neophobia. The latter was unmasked by a contributory influence of psychological stress, raising important implications for potential sensitizing and/or synergistic effects of systemic, immunological processes on adaptive neural mechanisms engaged by stress.

\section{MATERIALS AND METHODS}

\section{Animals}

Male BALB/cByJ mice (Jackson Laboratories, Bar Harbor, ME) arrived at 5-6 weeks of age and were acclimated for 10-14 d before experimentation. Food and water were provided ad libitum, under conditions of group housing ( $n=4$ per cage) and $12 \mathrm{hr}$ light/dark illumination (lights on at 7:00 A.M.). All experimental procedures were approved by the University of Pittsburgh Institutional Animal Care and Use Committee.

\section{Drugs and reagents}

Staphylococcal enterotoxin B (SEB) was purchased from Sigma (St Louis, MO), lipopolysaccharide (LPS; from E. coli 055:B5) from Difco (Detroit, MI), and recombinant human interleukin-1 $\beta$ (IL-1 $\beta$ ) from R \& D Systems (Minneapolis, MN). Indomethacin (Sigma) was dissolved in $4 \%$ sodium bicarbonate. Sheep anti-rat CRH for in vivo immunoneutralization of blood-borne CRH was a kind gift from Dr. Wylie Vale (Salk Institute, CA). Rat anti-mouse IL-2 was from Genzyme (Cambridge, MA). Plasmids containing exonic segments of mouse IL-2 and CRH genes were provided by Cynthia Watson (National Institute of Allergy and Infectious Diseases) and Dr. Audrey Seasholtz (University of Michigan, Ann Arbor), respectively.

\section{Neuroendocrine and histochemical studies}

Animals $(\sim 25 \mathrm{gm}$ in weight) were injected intraperitoneally with either $50 \mu \mathrm{g}$ of SEB or pyrogen-free $0.9 \%$ saline (Baxter Healthcare, Deerfield, IL). This dose of SEB was found to be optimal, as determined by dose-response studies published previously (Shurin et al., 1997). In some experiments, additional groups of animals were injected intraperitoneally with $50 \mathrm{ng}$ of human IL-1 $\beta$. In experiments designed to immunoneutralize CRH and IL-2, the animals were pretreated with $0.2 \mathrm{ml}$ of undiluted sheep anti-rat CRH or $200 \mu \mathrm{g}$ of rat anti-mouse IL-2. To test the effects of indomethacin (INDO), we briefly restrained the animals (no more than $1 \mathrm{~min}$ ) in mouse tail bleeding tubes and administered 10 $\mathrm{mg} / \mathrm{kg}$ INDO via a tail vein. Then $2 \mathrm{hr}$ later they were challenged with $50 \mu \mathrm{g}$ of SEB or $50 \mathrm{ng}$ of IL-1 $\beta$. In most experiments, death routinely occurred $2 \mathrm{hr}$ after injection, between 12:00 P.M. and 2:00 P.M. The $2 \mathrm{hr}$ time point was found in previous studies to be the peak time of the plasma ACTH and corticosterone response to SEB. However, for certain experiments the animals also were killed after 4,6 , and $24 \mathrm{hr}$ to assess splenic and neuronal CRH and IL-2 mRNA levels by in situ hybridization.

For the determination of hormonal and cytokine concentrations, the animals were decapitated, and trunk blood was collected into chilled EDTA-coated Vacutainer tubes (Beckton Dickinson, Rutherford, NJ).

\section{Behavioral studies}

\section{Conditioned taste aversion}

An experiment was conducted to test whether SEB challenge induces conditioned taste aversion (CTA), a form of associative learning that routinely occurs when animals experience illness after ingesting a novel drinking solution (Yamamoto et al., 1994). An additional experiment tested whether conditioned taste aversion could be induced by using LPS, as reported in the literature (Exton et al., 1995; Janz et al., 1996). Initially, group-housed mice were habituated every second day to placement in individual cages for $1 \mathrm{hr} / \mathrm{d}$. Animals were given a total of five preexposures. This procedure was introduced to attenuate any effects of a new environment on consumption of a novel drinking solution. On the training day ( $2 \mathrm{~d}$ after the final preexposure to the drinking environment) the animals were separated into individual cages (as on habituation days) and presented with the conditioning stimulus (CS). The CS was Prosobee (Mead Johnson, Evansville, IN), a commercial infant formula liquid, and was presented in a $50 \mathrm{ml}$ tube fit with a conventional metallic sipper tube. Preliminary studies had shown that animals voluntarily will consume this solution without the need for fluid deprivation. Animals were allowed to drink the solution for $1 \mathrm{hr}$, after which they were removed individually and injected intraperitoneally with either 50 $\mu \mathrm{g}$ of SEB or an equal volume $(0.2 \mathrm{ml})$ of nonpyrogenic saline. Our previous published results had shown this dose of SEB to be sufficient in activating the HPA axis and had shown that doubling the dose of SEB did not enhance this activation (Shurin et al., 1997). More to the point, in conducting this experiment we were interested in determining whether the HPA activation that occurs in response to $50 \mu \mathrm{g}$ of SEB is secondary to or associated with any illness effects.

Overall, there was a total of three main treatment groups, all of which received the CS solution at the same time: (1) conditioned animals were treated with SEB (or $5 \mu \mathrm{g}$ of LPS) immediately after drinking the CS solution; (2) nonconditioned animals received noncontingent pairing of the CS and SEB (or LPS), in that the animals were treated with SEB (or LPS) $24 \mathrm{hr}$ before CS exposure-i.e., no further injections were provided to this group after they drank the CS on the training day; and (3) placebo animals were injected with saline either immediately after CS exposure on the training day (P1 group) or were injected with saline 24 $\mathrm{hr}$ earlier (P2 group) to simulate conditions experienced by the nonconditioned group. Animals were returned to their original cages and group housing until the test day ( $1 \mathrm{~d}$ after conditioning when the UCS was SEB and $3 \mathrm{~d}$ after when the UCS was LPS). On the test day the animals were reexposed to the CS solution for $1 \mathrm{hr}$ as on the training day. After the test session the animals were returned to their group housing and tested again on 2-3 more consecutive days. Measures of consumption (expressed in grams) were determined by weighing the drinking tubes before and after each drinking session.

\section{Disruption of fluid ingestion}

Two experiments were conducted to test whether an injection of $50 \mu \mathrm{g}$ of SEB disrupts ongoing consumption of a familiar drinking solution. Thus, two groups of mice were presented with Prosobee for $1 \mathrm{hr} / \mathrm{d}$ for 2-4 d, and on the test day they were injected with either saline or $50 \mu \mathrm{g}$ of SEB $2 \mathrm{hr}$ before another drinking session. Consumption over a $1 \mathrm{hr}$ period was measured as in the taste aversion experiments. As with the above experiments the animals were habituated to separation and placement into a new environment.

\section{Taste neophobia}

Three experiments assessed the level of consumption of a novel solution in control and SEB-challenged animals. Exposure to novel stimuli, in particular food and contextual surroundings, elicits a form of avoidance behavior that suggests the presence of neophobia or fear of novelty. This behavior is the basis of many common tests of anxiety, especially those assessing anxiogenic and/or anxiolytic treatments (Stout and Weiss, 1994).

Experiment 1. Mice were challenged with saline or $50 \mu \mathrm{g}$ of SEB $(n=$ 8 per group) $2 \mathrm{hr}$ before being placed individually into a cage other than their home cage, where they were allowed to consume for $1 \mathrm{hr}$ an 
unfamiliar drinking solution. The novel cages were in a separate room from that in which the colony was housed. The novel drinking solution was Prosobee (see above). The environment into which animals were placed was made of opaque polypropylene and was fit with an empty (save for the bottle containing the drinking solution) standard stainless steel cage top. The physical dimensions of the cage were the same as the home cage (12 inches in length, 7 inches in depth, and 5 inches in width). The floor was covered with fresh wood shavings.

Experiment 2. Animals were challenged as in Experiment 1 and subsequently were exposed to either a novel or familiar cage containing an unfamiliar drinking solution. Novelty, under these circumstances, was defined as the first such experience for an animal (i.e., removal from the group and relocation to the new cage for $1 \mathrm{hr}$ ). Alternatively, familiarity was promoted by previous daily exposure (Habituation) to this process of removal into an individual cage. During habituation the animals remained in the cage for $1 \mathrm{hr}$, after which they were returned to the home cage in the colony room. For this experiment there was a total of four groups ( $n=8$ per group): (I) $\mathrm{SEB} / \mathrm{N}$, (II) $\mathrm{SEB} / \mathrm{H}$, (III) SAL/N, and (IV) $\mathrm{SAL} / \mathrm{H}$. In all groups the mice had never been exposed before to the distinct drinking solution, or any other solution, except for drinking water in their home cage. Thus, for all groups the Prosobee formula solution was a novel taste stimulus, whereas the drinking environment and relocation to this environment were familiar only to groups II and IV. This latter process of familiarization to $1 \mathrm{hr}$ of individual housing (Groups II and IV) occurred over a period of $10 \mathrm{~d}$, with animals being placed into individual housing every other day. Animals in groups I and III were handled on the same days. Handling for these animals consisted of being picked up briefly by the tail and put back down into a holding cage for $1 \mathrm{~min}$. The holding cage had the same characteristics as the home cage. Once all animals from the same home cage had been handled in this way, they were returned immediately to the home cage.

Experiment 3. In contrast to the previous experiment, Experiment 3 manipulated the familiarity of the distinct drinking solution by preexposing one set of animals $(n=16)$ to Prosobee in their home cage while another set of animals $(n=16)$ simultaneously was presented with a bottle of water. These preexposures occurred on two consecutive days, and each lasted $1 \mathrm{hr}$. On the third day, one-half of the animals in each set were injected either with saline or SEB and $2 \mathrm{hr}$ later were exposed to a new drinking environment, as in Experiment 1.

\section{Effect of novelty on plasma $A C T H$}

Additional experiments were conducted to determine whether the placement of group-housed animals into an individual housing condition served as a novelty stressor. For these experiments, plasma ACTH levels were assessed 15 and $30 \mathrm{~min}$ after individual placement into a novel cage. Control animals were picked up briefly by the tail but returned immediately to the home cage. These experiments were conducted to determine the neuroendocrine impact of relocation to a novel environment.

\section{In situ hybridization (ISH)}

\section{Prehybridization}

Brains and spleens were removed quickly, frozen in TissueTek OCT compound by immersion in 2 -methyl butane at $-30^{\circ} \mathrm{C}$, and stored at $-70^{\circ} \mathrm{C}$ until Cryostat-cut coronal sections (10 to $12 \mu \mathrm{m}$ thick) were obtained from the optic chiasm to the mamillary bodies. Tissue sections

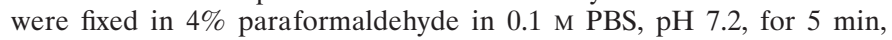
followed by a 3 min rinse with $0.1 \mathrm{M}$ PBS and dehydration through a graded series of ethanols $(50,70$, and $95 \%$, for 1 min each). To reduce nonspecific binding of the riboprobe, we neutralized positive charges by a 10 min incubation in $0.25 \%$ acetic anhydride containing $0.1 \mathrm{M}$ triethanolamine, $\mathrm{pH}$ 8.0. Sections then were rinsed with $0.2 \times \mathrm{SSC}$, dehydrated through a graded series of ethanols, and dried.

\section{Preparation of radiolabeled $R N A$ probes}

Detection of CRH and IL-2 mRNA was accomplished with antisense ${ }^{35} \mathrm{~S}$-labeled riboprobes. The CRH mRNA probe was generated from a linearized pGem $4 \mathrm{Z}$ plasmid containing a 578 bp DNA fragment from exon II of the mouse CRH gene [(Keegan et al., 1994), kindly provided by Dr. A. Seasholtz, University of Michigan]. The IL-2 mRNA probe was generated from a pGEM-1 plasmid containing a $600 \mathrm{bp}$ fragment of mouse IL-2 cDNA (kindly provided by Cynthia Watson, National Institute of Allergy and Infectious Diseases). Plasmids were linearized by digestion with HindIII (New England Biolabs, Beverly, MA), and antisense RNA probe transcription was conducted from the SP6 promoter with the Promega Riboprobe Transcription System (Promega Biotech, Madison, WI) as follows. Each $20 \mu \mathrm{l}$ reaction contained $1 \mu \mathrm{g}$ of linearized plasmid DNA, transcription-optimized buffer ( $40 \mathrm{~mm}$ Tris- $\mathrm{HCl}, \mathrm{pH}$ 7.5, $6 \mathrm{mM} \mathrm{MgCl}_{2}, 2 \mathrm{~mm}$ spermidine, $10 \mathrm{~mm} \mathrm{NaCl}$ ), 20 U SP6 RNA polymerase, $2.5 \mathrm{~mm}$ each of ATP, CTP, and UTP, $100 \mu \mathrm{M} \mathrm{CTP}, 100 \mathrm{~mm}$ dithiothreitol (DTT), $20 \mathrm{U}$ RNase inhibitor, and $62.5 \mu \mathrm{Ci}{ }^{35} \mathrm{~S}-\mathrm{UTP}$ (specific activity $\sim 2 \times 10^{7} \mathrm{cpm} / \mathrm{pmol}$; DuPont NEN, Boston, MA). The reaction was allowed to proceed for $1 \mathrm{hr}$ at $37^{\circ} \mathrm{C}$, whereafter the DNA template was removed by a $15 \mathrm{~min}$ incubation at $37^{\circ} \mathrm{C}$ with $1 \mathrm{U}$ RQ1 DNase (Promega), followed by centrifugation over a G-50 Sephadex column (Boehringer Mannheim, Indianapolis, IN). One microliter of the eluant was counted on a $\beta$-counter to ensure a count of $210-700 \times 10^{5}$ disintegrations per minute (DPM). For the control sense probe, plasmid DNA was linearized with EcoRI, and transcription was performed as above, using T7 RNA polymerase.

\section{Hybridization}

Antisense or sense radiolabeled probes were diluted in hybridization buffer to yield a specific activity of $2 \times 10^{6} \mathrm{DPM}$ per $100 \mu \mathrm{l}$. The hybridization buffer consisted of $0.6 \mathrm{M} \mathrm{NaCl}, 10 \mathrm{~mm}$ Tris, $\mathrm{pH} 7.4,1 \mathrm{~mm}$ EDTA, pH 8, $0.1 \mathrm{mg} / \mathrm{ml}$ sheared salmon sperm DNA (Stratagene, La Jolla, CA), $0.05 \mathrm{mg} / \mathrm{ml}$ yeast transfer RNA (Stratagene), $10 \mathrm{mg} / \mathrm{ml}$ total yeast RNA (Ambion, Austin, TX), $1 \times$ Denhardt's solution, $10 \%$ dextran sulfate, $50 \%$ redistilled formamide (Kodak, Rochester, NY), $0.1 \%$ SDS, $0.1 \%$ nathiosulfate, and $0.1 \mathrm{M}$ DTT (Stratagene). Approximately 25 $\mu \mathrm{l} /$ tissue of the hybridization mixture $\left(5 \times 10^{5} \mathrm{DPM}\right)$ was applied to each slide $(50 \mu \mathrm{l}$ per slide). Then the slides were coverslipped and incubated for $16 \mathrm{hr}$ in a $50 \%$ formamide atmosphere at $55^{\circ} \mathrm{C}$.

\section{After hybridization}

After hybridization the slides were soaked in $2 \times$ SSC to remove coverslips and rinsed for a further $5 \mathrm{~min}$ in fresh $2 \times \mathrm{SSC}$. Then the slides were treated with $2 \mu \mathrm{g} / \mathrm{ml}$ ribonuclease A (RNase A, Boehringer Mannheim) in RNase buffer (40 mm Tris, $\mathrm{pH} 8.0,0.5 \mathrm{M} \mathrm{NaCl}$, and $1 \mathrm{~mm}$ EDTA) for $30 \mathrm{~min}$ at $37^{\circ} \mathrm{C}$. This was followed by an additional $30 \mathrm{~min}$ incubation at $37^{\circ} \mathrm{C}$ in RNase-free RNase buffer and then a 5 min rinse at $37^{\circ} \mathrm{C}$ in $2 \times$ SSC. All sections were subjected to a series of washes as follows: $45 \mathrm{~min}$ at $50^{\circ} \mathrm{C}$ in $2 \times \mathrm{SSC}, 45 \mathrm{~min}$ at $55^{\circ} \mathrm{C}$ in $0.2 \times \mathrm{SSC}$, and $45 \mathrm{~min}$ at $60^{\circ} \mathrm{C}$ in $0.1 \times$ SSC. The tissue sections were dehydrated through a series of $2 \mathrm{~min}$ washes in $50,70,80$, and $90 \%$ ethanol/0.3 $\mathrm{M}$ sodium acetate, with a final $5 \mathrm{~min}$ in $100 \%$ ethanol. Subsequently, the sections were air-dried and subjected to film autoradiography.

Film autoradiography was conducted by exposing slides for $4 \mathrm{~d}$ to Kodak BioMax film in light-tight $\mathrm{x}$-ray cassettes. Calibration of exposure intensity was achieved by exposing the film to ${ }^{14} \mathrm{C}$ plastic strips (American Radiolabeled Chemicals, St. Louis, MO) of variable specific activity (46.4-1580 DPM). After film development the slides were dipped at $45^{\circ} \mathrm{C}$ in emulsion (type NTB2, Kodak number 165-4433) and incubated at $4^{\circ} \mathrm{C}$ in light-tight slide racks for $10 \mathrm{~d}$. They subsequently were developed in Kodak Dektol solution $\left(2 \mathrm{~min}\right.$ at $\left.15^{\circ} \mathrm{C}\right)$ and fixed in Kodak fixer $(5 \mathrm{~min}$ at $15^{\circ} \mathrm{C}$ ). The slides were counterstained with nuclear red (Vector Laboratories, Burlingame, CA) and stored in a safe location until they were ready for examination by optical microscopy under dark- and light-field conditions.

\section{Semiquantitation of in situ hybridization autoradiographs}

Semiquantitation of autoradiographic images was achieved by using SigmaScan image analysis software (SPSS Science, Chicago, IL). For the brain a calibration curve was established on the basis of the gray level intensity of autoradiographs obtained from different radioactive concentrations of ${ }^{14} \mathrm{C}$ standards (American Radiolabeled Chemicals), as described by others (Miller, 1991; Brady et al., 1994). Units of measurement were DPM, and these were used to quantitate the activity from four to six sections per animal of the left and right PVN and central nucleus of the amygdala (ceA). A nonhybridized region outside of the PVN and ceA was quantitated also, and this was subtracted from the value obtained for the region of interest to give a final net value in DPM of antisense RNA probe hybridization. A similar semiquantitation procedure that used the ${ }^{14} \mathrm{C}$ calibration curve was applied for the spleen, in that all areas in the white pulp of the spleen that showed hybridization for the antisense IL-2 RNA probe were quantitated and adjusted for background obtained in nonhybridized regions. In all experiments the sense RNA probes showed no hybridization when applied to the spleen and brain. Selective RNase 



Figure 1. IL-2 transcription is increased in the spleens of mice 2, 4, and $6 \mathrm{hr}$ after SEB challenge. Mice were challenged intraperitoneally with $50 \mu \mathrm{g}$ of SEB at 0, 2, 4, or $6 \mathrm{hr}$ before death and assessment of IL-2 mRNA by in situ hybridization of spleen tissue sections. Unchallenged mice $(A)$ showed no detectable levels of IL-2 mRNA in the lymphocyte-rich white pulp $(W P)$ regions of the spleen. This was not the case $2 \mathrm{hr}(B)$ and $4 \mathrm{hr}(C)$ after SEB challenge. Hybridization for IL-2 mRNA was dramatic at these times and confined principally to the WP regions (arrows) rather than to the macrophage-enriched red pulp $(R P)$. The level of hybridization decreased appreciably by $6 \mathrm{hr}(E)$. This is more clearly evident by comparing the images in $D$ and $F$, which offer higher magnification views of silver grain density within the dotted circles in $C$ ( $4 \mathrm{hr})$ and $E$ ( $6 \mathrm{hr})$, respectively. Scale bars: $A-C$, $E, 200 \mu \mathrm{m} ; D, F, 20 \mu \mathrm{m}$.

treatment of tissue sections before hybridization with antisense RNA probes failed to result in any hybridization.

\section{Assays for ACTH and IL-2}

Blood was collected into EDTA-coated tubes and centrifuged at 2500 $\mathrm{rpm}$ for $15 \mathrm{~min}$ at $4^{\circ} \mathrm{C}$. Plasma was collected and stored at $-70^{\circ} \mathrm{C}$ in separate tubes designated for ACTH and IL-2 measurements. Hormonal measurements were achieved by commercial radioimmunoassay kits pur- chased from ICN Biochemicals (Irvine, CA). Cytokine measurements were performed with ELISA reagents purchased from Endogen (Cambridge, MA).

\section{Statistical analysis}

Where it was deemed necessary, data were analyzed by ANOVA or Bonferroni $t$ test. Significant main effects obtained from ANOVA were analyzed further by a post hoc Tukey test, whereas interaction effects 
Table 1. Plasma IL-2 and ACTH concentrations 2, 4, or 6 hrs after SEB treatment

\begin{tabular}{llc} 
Time $(\mathrm{hr})$ & Plasma IL-2 $(\mathrm{ng} / \mathrm{ml})$ & Plasma ACTH $(\mathrm{pg} / \mathrm{ml})$ \\
\hline 0 & $0.78 \pm 0.07$ & $40.4 \pm 4.1$ \\
2 & $43.9 \pm 9.3$ & $158.5 \pm 12.1$ \\
4 & $19.8 \pm 4.0$ & $189.6 \pm 45.0$ \\
6 & $7.58 \pm 0.6$ & $72.8 \pm 15.9$
\end{tabular}

All animals were killed around the same time of the day to avoid circadian influences. All values for 2, 4, and $6 \mathrm{hr}$ time points were significantly different $(p<$ 0.05 ) from $0 \mathrm{hr}$, which in the case of ACTH represented collapsed values for animals injected with saline $0,2,4$, or 6 hrs before death.

$n=6-8$ for each time point, except $n=24$ for $0 \mathrm{hr}$, ACTH column.

were explored by contrast analysis of group means. Treatment effects or group differences were considered to be significant at $p<0.05$.

\section{RESULTS}

\section{Stimulation of splenic IL-2 transcription and associated CRH mRNA expression in the brains of SEB-challenged mice}

Animals were challenged with saline or SEB at 0,2 , 4, or $6 \mathrm{hr}$ before death at the same time of the day. For all of the reported measures, saline-injected animals did not differ from animals killed immediately at $0 \mathrm{hr}$. Therefore, only the data for the $0 \mathrm{hr}$ group are presented in relation to results obtained from SEBinjected animals. To confirm T-cell activation, we assayed spleens and plasma for IL-2 mRNA and protein levels. As is evident in Figure 1, after SEB challenge there was a dramatic induction of IL-2 mRNA in the spleen. The level of IL-2 mRNA was high for several hours ( $4 \mathrm{hr}$ time point) but was found to decline by $6 \mathrm{hr}$ (Fig. 1). No IL-2 mRNA was detected in the spleens of animals killed at $0 \mathrm{hr}$. As reported previously (Shurin et al., 1997), plasma IL-2 and ACTH concentrations displayed the same kinetics of response, with IL-2 achieving nanogram concentrations by $2 \mathrm{hr}$ and declining by $6 \mathrm{hr}$ (Table 1 ).

Determination of CRH mRNA levels was conducted on the brains and spleens of animals in the $0,2,4$, and $6 \mathrm{hr}$ groups. There was no detectable hybridization for CRH mRNA in the mouse spleens at any time point (data not shown). However, significant hybridization was observed in brains, in particular the PVN of the hypothalamus and ceA (Figs. 2, 3). Figure 4 shows the calculated mean DPM for the PVN and ceA. A one-way ANOVA of DPM obtained from the ceA revealed a significant effect of time $\left(F_{(3,22)}\right.$ $=4.23 ; p<0.025)$. Additional post hoc analysis with the Tukey test confirmed that the mean DPM for the 4 and 6 hr groups was each significantly higher ( $p=0.05$ and $p=0.036$, respectively) than the $0 \mathrm{hr}$ group. The 0 and $2 \mathrm{hr}$ groups did not differ from each other. Similarly, one-way ANOVA of the PVN data revealed a significant effect of time $\left(F_{(3,22)}=4.8 ; p<0.025\right)$, which was attributable to significantly higher DPM in the $6 \mathrm{hr}$ group relative to the $0 \mathrm{hr}$ group (Tukey test, $p=0.019$ ). For the PVN the level of CRH mRNA for the 2 and $4 \mathrm{hr}$ groups did not achieve the criterion for statistical significance relative to the $0 \mathrm{hr}$ group.

\section{Immunoneutralization of circulating $\mathrm{CRH}$ blocks the ACTH response to SEB}

The increased transcription of $\mathrm{CRH}$ in the PVN suggested that the high concentration of plasma ACTH observed after SEB challenge may be mediated by $\mathrm{CRH}$ secretion into the median eminence. To test this, we treated mice intraperitoneally with 0.2 $\mathrm{ml}$ of undiluted sheep anti-rat $\mathrm{CRH}$ antiserum and 15 min later challenged them intraperitoneally with $50 \mu \mathrm{g}$ of SEB. Animals were killed $2 \mathrm{hr}$ after the SEB challenge. Analysis of plasma ACTH values revealed a significant interaction effect between toxin challenge and serum administration $\left[F_{(1,23)}=15.15 ; p<\right.$ 0.001]. As shown in Figure $5 A$, this was attributable to the greatly attenuated ACTH response in SEB-challenged animals who were administered the anti-CRH antiserum.

\section{Indomethacin treatment or immunoneutralization of IL-2 failed to block the ACTH response to SEB}

Prostaglandin synthesis has been implicated in the HPAactivating effects of the proinflammatory cytokine IL-1, and a similar mechanism may be involved in SEB-mediated HPA axis stimulation. Figure $5 B$ presents the plasma ACTH concentrations in saline, SEB, and rhIL- $1 \beta$-challenged animals who were administered indomethacin or vehicle. The rhIL-1 $\beta$ group was included as a positive control of the ability of indomethacin to block the ACTH response to this cytokine. A two-way (Drug $\times$ Challenge) ANOVA revealed only a significant effect of Challenge $\left(F_{(1,34)}=\right.$ 6.11; $p<0.01$ ), but no Drug or Drug $\times$ Challenge effects. Because the IL-1 group was included as a positive control and the literature allowed us to expect an effect of indomethacin treatment, we conducted orthogonal contrasts comparing the two rhIL-1 $\beta$ groups. This revealed a significant difference $(F=4.16 ; p<0.05)$ and confirmed what is clearly evident in Figure $5 B$ as a marked reduction of ACTH levels in indomethacin-treated rhIL-1 $\beta$ animals.

Excessive exposure to IL-2 can stimulate the HPA axis (Hanisch et al., 1994). Therefore, we tested whether the immunoneutralization of circulating IL-2 would alter the increased ACTH response to SEB challenge by pretreating animals with rat antimouse IL-2 monoclonal antibody or nonimmune rat IgG. The results showed that anti-mouse monoclonal antibody treatment reduced plasma IL-2 levels to near-baseline concentrations as measured by ELISA [SEB + rat anti-IL-2, $1.34 \pm 0.4 \mathrm{ng} / \mathrm{ml}$; SEB + rat $\mathrm{IgG}, 10.73 \pm 1.5 \mathrm{ng} / \mathrm{ml}$. However, this apparently effective immunoneutralization of circulating IL-2 did not alter the increase in plasma ACTH observed in response to SEB challenge $[\mathrm{SEB}+$ rat IgG $(n=5), 77.1 \pm 17.9 \mathrm{pg} / \mathrm{ml}$; SEB + rat anti-IL-2 $(n=7), 73.8 \pm 13.0 \mathrm{pg} / \mathrm{ml}$; saline + rat $\operatorname{IgG}(n=4), 28.25 \pm 7.4$ $\mathrm{pg} / \mathrm{ml}$; saline + rat anti-IL-2 $(n=4), 26.7 \pm 4.9]$.

\section{T-cell activation with SEB augments taste neophobia in the absence of illness effects}

Behavioral experiments were initiated to determine whether T-cell activation with SEB produced a generalized illness that could be associated with the neural effects of SEB challenge. The results of a conditioned taste aversion experiment failed to show that pairing a novel taste solution (conditioning stimulus) with SEB challenge results in the development of a learned aversion to the CS that is linked to T-cell activation (data not shown). Additional experiments showed that SEB challenge did not disrupt ongoing consumption of a familiar drinking solution or produce overnight changes in body weight (data not shown, but consider Fig. 6). In over a dozen experiments visual inspection of SEB-challenged animals in their home cages at the time they were to be removed for death or behavioral assessment did not reveal piloerection or reduced activity.

Because of the apparent lack of illness-like effects caused by challenge with SEB, appetitive behavior was assessed under conditions designed to probe neophobic behavior. As shown in Figure $6 A$, animals challenged with SEB and $2 \mathrm{hr}$ later exposed to a novel drinking solution displayed reduced consumption of a 



Figure 2. SEB increases CRH mRNA levels $6 \mathrm{hr}$ after challenge in the hypothalamus (PVN) and amygdala (ceA). This figure shows representative autoradiographic film images (insets) and dark-field silver grain formation of the ceA and PV N from subsequently emulsion-dipped slides. $A$, ceA/control. $B$, ceA/SEB. $C$, PVN/control. $D$, PVN/SEB. Scale bars: $A-D$, Dark field, $100 \mu \mathrm{m}$; insets, $2 \mathrm{~mm}$.

novel drinking solution. A repeated measures ANOVA (Challenge $\times$ Test $)$ revealed significant effects of Challenge $\left(F_{(1,11)}=\right.$ 9.4; $p<0.025)$ and Test $\left(F_{(2,22)}=4.3 ; p<0.025\right)$. The absence of an interaction effect was consistent with the persistent difference in consumption between SEB- and saline-injected animals across the three test periods.

A replication of this experiment tested whether the novelty of the environment in which consumatory behavior was elicited influenced animals who were challenged with SEB. Figure $6 B$ shows the results of this experiment. A three-way ANOVA (Challenge $\times$ Habituation $\times$ Test) with repeated measures across the Test variable revealed significant effects of Challenge $\left(F_{1,28)}=\right.$ 5.8; $p<0.025)$, Habituation $\left(F_{(1,28)}=8.0 ; p<0.01\right)$, and Test $\left(F_{(2,56)}=107.7 ; p<0.0001\right)$ without any further main or interaction effects. The main effects of challenge and habituation were evidently a function of the reduced consumption by SEBchallenged animals who had received no previous habituation to being placed in the drinking environment (Fig. 6B). However, if the animals were familiarized with the drinking environment, SEB challenge did not influence consumption of the novel drinking solution differently from either of the saline-injected groups.

A final experiment tested whether the novelty of the drinking solution influenced the consumatory behavior of SEB-challenged animals. A two-way ANOVA (Taste Novelty $\times$ Challenge) conducted on the data in Figure $6 C$ showed a significant effect of
Taste Novelty $\left(F_{(1,28)}=29.2 ; p<0.0001\right)$ and interaction between Taste Novelty and Challenge $\left(F_{(1,28)}=15.1 ; p<0.001\right)$. The latter was likely a function of the greater consumption by SEB-challenged animals who were familiar with the drinking solution, as well as the markedly reduced consumption by the SEB-treated group unfamiliar with the drinking solution, which likely accounted for the significant main effect of Taste Novelty. A planned Bonferroni $t$ test comparing animals challenged with SEB and saline and subsequently exposed to novel drinking solution revealed a significant difference in consumption $\left(t_{(14)}=\right.$ 4.078; $p=0.001)$.

To test whether relocation to a novel drinking environment activated the HPA axis, we individually exposed different groups of naïve animals for 15 or 30 min to a novel environment identical to that in which appetitive behavior was tested in the foregoing experiments. Control animals were left in their home cages and killed at 15 and $30 \mathrm{~min}$. A two-way ANOVA (Novel Cage $\times$ Sampling Time) conducted on the plasma ACTH values revealed significant main effects of being placed in a novel cage $\left(F_{(1,28)}=\right.$ $15.3 ; p<0.001)$ as well as sampling time $\left(F_{(1,28)}=12.0 ; p<0.01\right)$. A borderline interaction also was observed $\left(F_{(1,28)}=3.4 ; p=\right.$ 0.076). The effect of being placed into a novel cage was clearly evident in the doubling of plasma ACTH concentrations by 30 min after removal from the home cage [Home Cage $15 \mathrm{~min}(n=$ 8), $54.3 \pm 7.3 \mathrm{pg} / \mathrm{ml}$; Home Cage $30 \mathrm{~min}(n=8), 69.0 \pm 9.4$ 


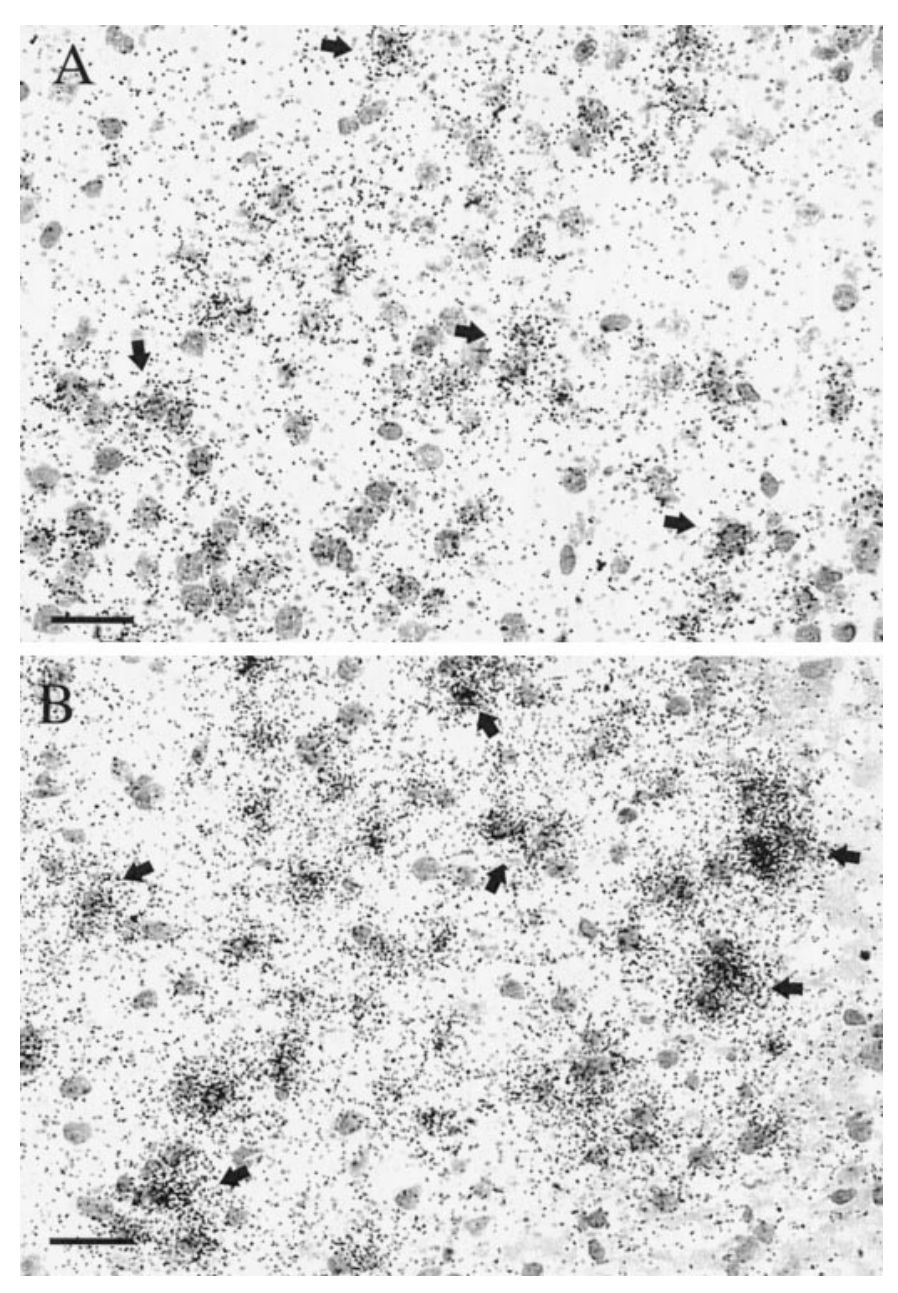

Figure 3. Increased CRH mRNA hybridization in the central nucleus of the amygdala $6 \mathrm{hr}$ after SEB challenge. The ceA region in emulsiondipped and nuclear-counterstained brain tissue sections were captured digitally under light-field illumination. $A$, Control. $B$, SEB. Clear evidence of more intense and numerous silver grain formation over cytoplasmic domains is evident in the SEB-challenged animal (compare the areas indicated by arrows). Scale bars: $A, B, 25 \mu \mathrm{m}$.

$\mathrm{pg} / \mathrm{ml}$; Novel Cage $15 \mathrm{~min}(n=8), 73.3 \pm 9.7 \mathrm{pg} / \mathrm{ml}$; Novel Cage $30 \mathrm{~min}(n=8), 121.5 \pm 9.8 \mathrm{pg} / \mathrm{ml}]$. This provided neuroendocrine confirmation of the anxiogenic properties of individual relocation from the home cage and into a novel environment in which the animals were alone and exposed to a novel drinking solution.

\section{DISCUSSION}

Neurocircuitry subserving emotional reactivity can be activated by processive - e.g., psychological—stimuli as well as by systemic events acting via interoceptive mechanisms (Herman and Cullinan, 1997). The latter includes signals derived from the immune system, and the results of the present series of experiments confirm that T-lymphocytes can mediate neural and behavioral effects similar to other immune cells, such as macrophages (Derijk et al., 1991). This was demonstrated by using staphylococcal enterotoxin $\mathrm{B}$ (SEB), a protein antigen that readily binds $\mathrm{MHC}$ class II molecules on antigen-presenting cells and then cross-links with specific motifs on the variable $(\mathrm{V})$ region of the $\beta$-chain of the T-cell receptor (Johnson et al., 1991). The $\mathrm{V} \beta 8^{+} / \mathrm{CD} 4^{+}$ $\mathrm{T}$-cell population is highly reactive to SEB, producing within 1-2

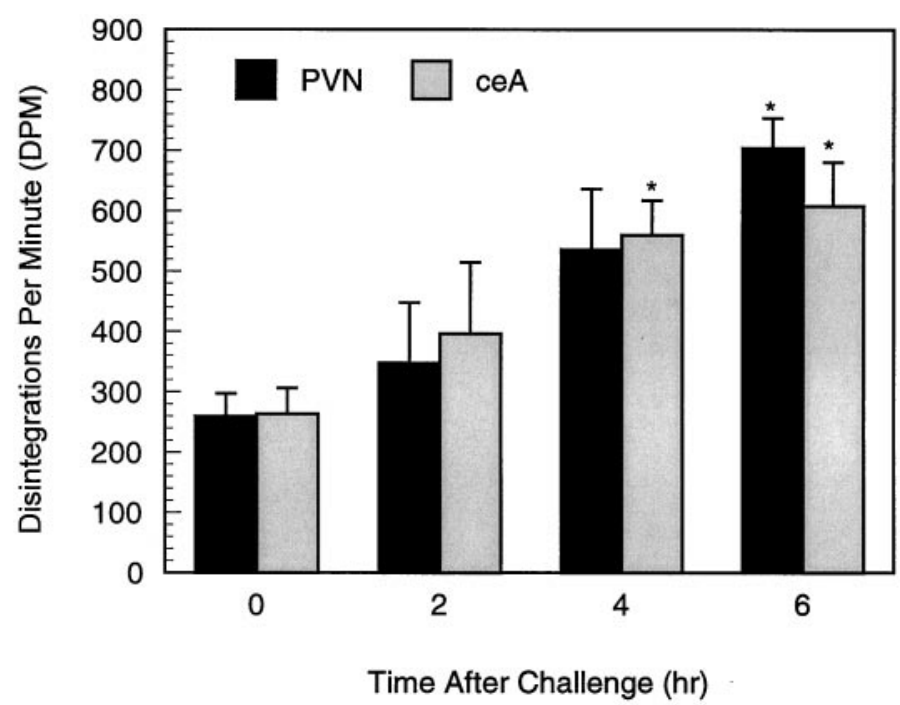

Figure 4. Mean disintegrations per minute $(\mathrm{DPM} \pm \mathrm{SE})$ in the PVN and ceA of CRH mRNA-hybridized brains from control and SEB-challenged animals. Animals were killed at the same time of day $0,2,4$, and $6 \mathrm{hr}$ after challenge with $50 \mu \mathrm{g}$ of SEB ( $n=6-8$ per group). Film autoradiographs were captured digitally and quantified as described in Materials and Methods. *Significantly different from $0 \mathrm{hr}$ at $p<0.05$.

hr highly measurable levels of cytokines and, in particular, IL-2 (Bette et al., 1993; Shurin et al., 1997). Such robust activation is impressive relative to the failure of most T-dependent protein antigens to induce cytokine production that achieves measurable quantities in plasma (Kelso et al., 1991; Troutt et al., 1992).

Consistent with this, the present results revealed prominent levels of splenic IL-2 mRNA and plasma IL-2 that persisted for up to $6 \mathrm{hr}$ after the initial challenge with SEB. This frank activation of T-cells was associated with increased CRH mRNA in the PVN and ceA. This was observed 4-6 hr after SEB challenge, whereas pituitary-adrenal and behavioral changes (see below) occur well before this (at $2 \mathrm{hr}$ ). It has been documented that cytoplasmic CRH mRNA levels are stable and increase slowly, whereas CRH heteronuclear RNA is transcribed readily within minutes of stressor exposure, presumably in anticipation of the need for compensatory increases in mRNA because of augmented translational events leading to CRH secretion (Imaki et al., 1995; Kovacs and Sawchenko, 1996). Although in situ hybridization data that use heteronuclear CRH riboprobes would clarify the present set of results, it is likely that the increased $\mathrm{CRH}$ mRNA after SEB challenge is evidence of compensation. In support of this, the increased plasma ACTH response at $2 \mathrm{hr}$ after SEB challenge was abolished by systemic immunoneutralization of $\mathrm{CRH}$, which suggests that the release of $\mathrm{CRH}$ from neurosecretory cells in the PVN may be the principal driving mechanism for the increased ACTH output. As for the amygdala, we can only speculate as to whether CRH release occurred at $2 \mathrm{hr}$ after SEB challenge, an event suggested by the likely compensatory increase in CRH mRNA at $4 \mathrm{hr}$ and $6 \mathrm{hr}$.

It could be argued that the immunoneutralizable $\mathrm{CRH}$ arose from SEB-activated immune cells, because CRH mRNA has been detected in rat and mouse lymphoid tissue (Aird et al., 1993; Muglia et al., 1994; Brouxhon et al., 1998). However, there is also evidence of a failure to detect lymphoid cell CRH mRNA (Stenzel-Poore et al., 1992; Bamberger et al., 1998), supported in the present study with the failure of control and activated spleens 


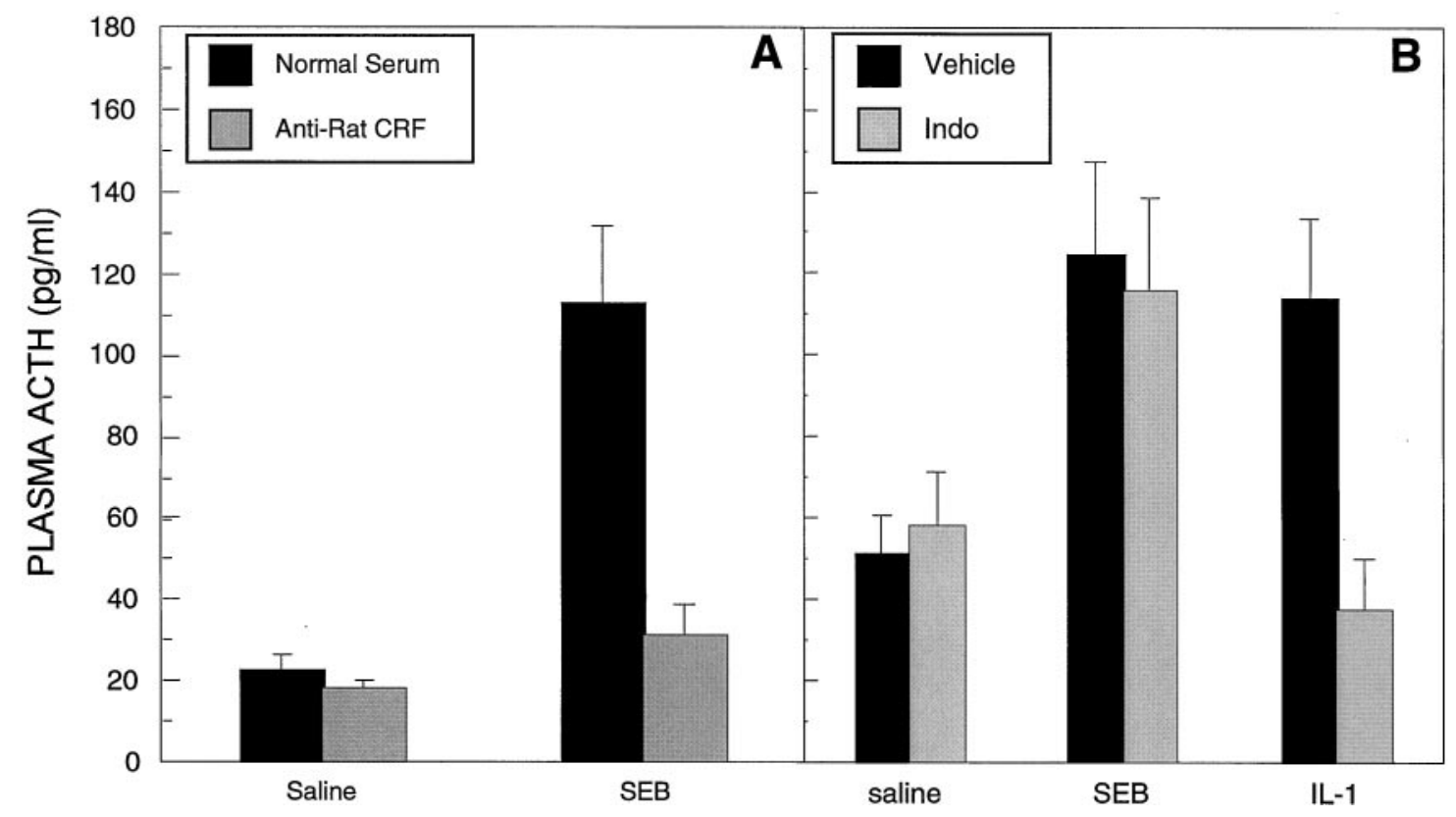

Figure 5. Effect of systemic CRH immunoneutralization and indomethacin treatment on plasma ACTH concentrations after SEB challenge. $A$, Animals were treated with either sheep anti-rat CRH or normal sheep serum and 15 min later were challenged intraperitoneally with $50 \mu \mathrm{g}$ of SEB or saline. It is evident that there was complete abrogation by anti-CRH treatment of the ACTH response to SEB $(n=6-9$ per group). B, Animals were treated intravenously with vehicle or indomethacin $(10 \mathrm{mg} / \mathrm{kg})$ and challenged with saline, $50 \mu \mathrm{g}$ of SEB, or $50 \mathrm{ng}$ of hIL-1 3 . Measurement of plasma ACTH $2 \mathrm{hr}$ later revealed no alteration because of INDO treatment in the elevated ACTH concentrations observed in SEB-challenged animals. A statistically significant reduction in plasma ACTH was observed in the IL-1 group pretreated with INDO (see Results).
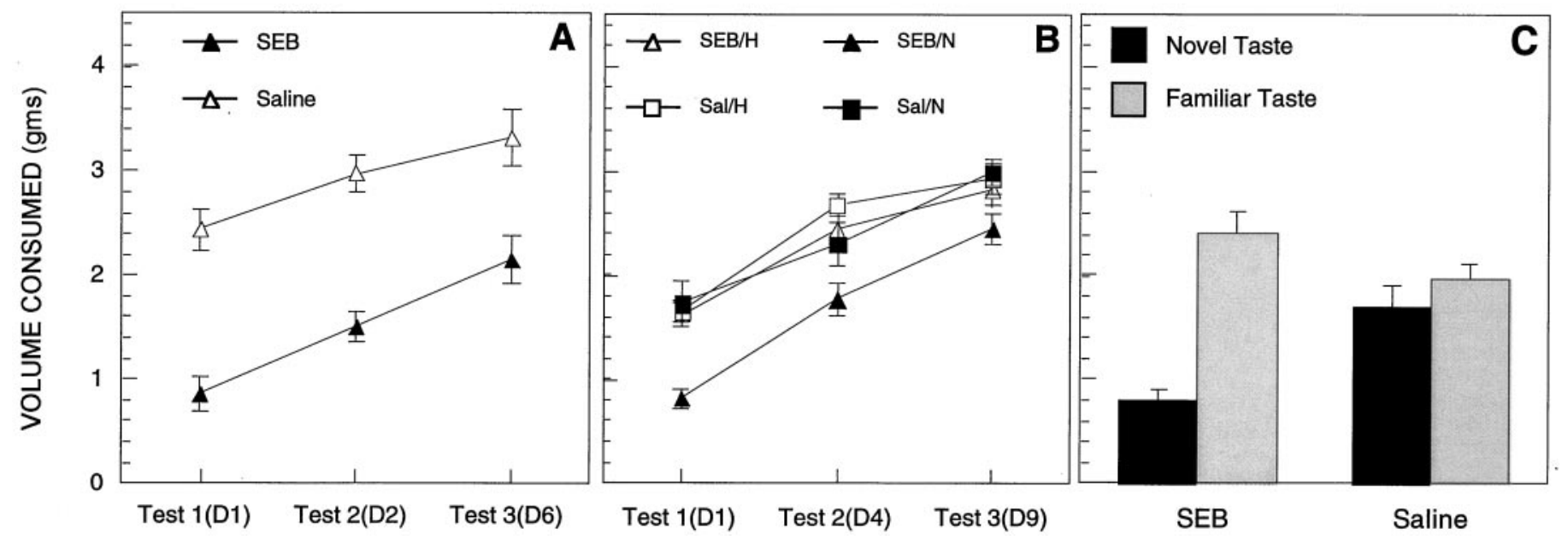

Figure 6. SEB challenge enhances the neophobic avoidance of a novel taste stimulus. Several experiments measured consumatory behavior under various conditions of environmental and food novelty (see Materials and Methods). Data represent the mean consumption \pm SE ( $n=6$ per group, Experiment 1; $n=8$ in Experiments 2 and 3; see Results for full statistical details). $A$, Effect of SEB challenge on consumption of a novel taste stimulus in a novel environment $2 \mathrm{hr}$ after challenge, Test 1. Animals were reexposed to the drinking situation (same environment and drinking stimulus) on the next day (Test 2, i.e., day 2) and on day 6 after challenge (Test 3 ). Consumption levels for SEB-challenged animals were reduced significantly. $B$, Different groups of animals were preexposed ( $H$, i.e., habituated) or remained naïve ( $N$, i.e., novel environment) to the drinking test environment. Consumption $2 \mathrm{hr}$ after SEB challenge was reduced significantly only if the environment was novel (Test 1, day 1). Consumption remained low on subsequent test days $(D 4$ and $D 9$ ) but displayed recovery. $C$, Effect of varying the novelty of the drinking stimulus. One group of animals was preexposed to the drinking stimulus in the home cage (Familiar Taste group) while another group received water (Novel Taste group). Consumption of the distinct drinking stimulus in a novel environment was measured $2 \mathrm{hr}$ after SEB or saline challenge. There was no effect on consumption by SEB challenge if the drinking stimulus was familiar.

(i.e., showing extensive IL-2 mRNA) to hybridize with the $\mathrm{CRH}$ riboprobe. Consequently, it is unlikely that neutralizable $\mathrm{CRH}$ in the present experiments was of immune origin.

Activation of T-cells with SEB increased CRH mRNA in the ceA. Amygdaloid function is fundamental to emotional responses (Davis, 1992), and CRH production in the ceA promotes anxiogenic functions (Rassnick et al., 1993; Rodriguez et al., 1997). Increased CRH mRNA and activity in the ceA have been observed in response to psychological stressors and challenge with endotoxin (Laflamme et al., 1997; Hsu et al., 1998; Merali et al., 1998), although in the latter the indirect effects of illness were not ruled out. In the present study the neural effects of SEB were 
shown not to be associated with various indices of illness, because animals lacked piloerection, loss of body weight, and reduced feeding. Moreover, although LPS effectively produces a conditioned taste aversion in BALB/cByJ mice (our unpublished observations), SEB challenge did not have the same conditioning properties. At higher doses of SEB than that used in the present experiments, illness effects might be possible, although this has been found to be inconsistent (Wood and Todd, 1995). However, the purpose of these experiments was to determine whether immunological challenge with SEB at a dose that reliably activates the CNS is associated with illness-like behavioral alterations. Given the lack of behavioral signs supporting this, it is unlikely that neural activation in response to SEB challenge involves cognitive reactivity to somatic sensations of malaise.

Additional experiments explored behavior that might reflect emotional reactivity. The amount of food or water consumed in a novel environment can be modulated by anxiolytic and anxiogenic agents (Stout and Weiss, 1994), and seemingly normal appetitive behavior can raise $\mathrm{CRH}$ activity in the ceA (Merali et al., 1998), implying that this form of behavior may have considerable emotional valency. Therefore, mice challenged with SEB were tested for consumption of a novel food substance presented in a similarly novel environment. The results showed significant suppression of consumatory behavior, which was governed by contextual novelty. However, although this was paramount, it was not sufficient to alter consumption of a familiar drinking solution in SEB-challenged mice (which incidentally confirmed that animals were not feeling ill). Ultimately, the necessary conditions for reduced consumption in the SEB-challenged animal were for both environmental context and gustatory stimulus to be novel. Indeed, the novelty of the environment was found to be stressful, as determined by plasma ACTH measures. Interestingly, the amygdala is required for HPA axis reactivity to psychological stressors (Van de Kar et al., 1991). Therefore, immunological challenge may sensitize animals to exhibit augmented neophobic behavior under conditions that most likely access neural substrates of emotionality, such as the amygdala.

Additional experiments are required to determine whether behavior in other paradigms that test anxiety and/or emotionality are altered by SEB challenge. Nonetheless, the present set of results argues strongly for an emotional influence of T-cell activation with SEB. As such, they are also consistent with other evidence showing the influence of autoimmune processes on emotional behavior in mice (Schrott and Crnic, 1996), although the mediatory role of T-cells in the latter is not known. In any case the behavioral effects of SEB may be a result of underlying changes in $\mathrm{CRH}$ gene transcription in the central nucleus of the amygdala. For example, despite evidence that centrally administered immune products, such as IL-1, influence novelty-induced behavior via a CRH-independent mechanism (Spadaro and Dunn, 1990), there is also evidence that systemically administered IL-1 can modify similar behavior via a mechanism that does involve CRH (Dunn et al., 1991). Although this is not to suggest that IL-1 mediates the behavioral effects of SEB, there does appear to be support for the hypothesis that peripheral immune processes may exert behavioral actions via recruitment of $\mathrm{CRH}$ synthesis and release. Such a direct link between behavior and CRH mRNA induction needs to be verified in the case of SEB.

The determination of central factors involved in activating CRH mRNA and neophobic behavior still remains. The presence of IL-1 in the hypothalamus has been suggested to influence the HPA axis; furthermore, central IL-1 receptors may influence the effects of stress on emotional learning (Maier and Watkins, 1995). However, in preliminary studies we did not observe induction of IL-1 $\beta$ mRNA in the hypothalamus after SEB challenge (our unpublished observations). Additional studies seeking to measure other cytokines and their receptors obviously are needed.

Previously, it was shown that treatment with cyclosporine A, which suppresses T-cell function by inhibiting IL-2 gene transcription, prevented the neuroendocrine effects of SEB challenge (Shurin et al., 1997). Interestingly, in the present study, immunoneutralization of IL-2 did not alter the ACTH response to SEB challenge. This is consistent with other evidence in which acute, but not chronic, administration of IL-2 fails to stimulate the HPA axis in rats and mice (Hanisch et al., 1994; Zalcman et al., 1994). Furthermore, the lack of IL-2 involvement in HPA activation is supported by similar noninvolvement in anxiogenic behavior in the elevated plus maze (Connor et al., 1998). However, IL-2 can stimulate the production of CRH by amygdaloid tissue (Raber et al., 1995), and limbic regions express IL-2 receptors (Hanisch and Quirion, 1995). Furthermore, IL-2 exerts anhedonic effects (Anisman et al., 1996; Hebb et al., 1998), which may or may not be operational in the present set of results. Although SEB challenge did not affect the palatability of the taste stimulus when it was familiar or consumed in a familiar context, it remains to be determined whether immunological challenge alters the manner in which novelty influences the hedonic properties of an otherwise palatable diet. As noted above, evidence that $\mathrm{CRH}$ release in the ceA is provoked by a normal eating bout (Merali et al., 1998) implies some form of arousal, but the significance of this is unknown. In short, although immunoneutralization of IL-2 does not affect SEB-induced HPA axis activation, future studies will determine whether neutralizing IL-2 or other cytokines alters the observed changes in behavior and CRH mRNA.

The generation of arachidonic acid metabolites, such as prostaglandin E, does not appear to be involved in the ACTH response to SEB, because indomethacin treatment did not affect ACTH output in challenged mice. However, consistent with the literature (Buller et al., 1998), pituitary-adrenal activation because of IL-1 $\beta$ was attenuated significantly by indomethacin. This raises an interesting question as to whether HPA reactivity to SEB involves IL-1. Previously, we found that IL-1 production in response to $\mathrm{SEB}$ did not achieve readily detectable levels in plasma but could be measured in lymphoid tissue, such as the spleen, in which antigen-presenting cells are most likely the source of IL-1 (Shurin et al., 1997). Therefore, its role in mediating the neural and behavioral effects of SEB challenge via at least humoral mechanisms remains uncertain and requires further investigation.

\section{REFERENCES}

Aird F, Clevenger CV, Prystowsky MB, Redei E (1993) Corticotropinreleasing factor mRNA in rat thymus and spleen. Proc Natl Acad Sci USA 90:7104-7108.

Anisman H, Zacharko RM (1992) Depression as a consequence of inadequate neurochemical adaptation in response to stressors. Br J Psychiatry [Suppl] 36-43.

Anisman H, Zalcman S, Zacharko RM (1993) The impact of stressors on immune and central neurotransmitter activity: bidirectional communication. Rev Neurosci 4:147-180.

Anisman H, Kokkinidis L, Merali Z (1996) Interleukin-2 decreases accumbal dopamine efflux and responding for rewarding lateral hypothalamic stimulation. Brain Res 731:1-11.

Bamberger CM, Wald M, Bamberger AM, Ergun S, Beil FU, Schulte HM (1998) Human lymphocytes produce urocortin, but not corticotropinreleasing hormone. J Clin Endocrinol Metab 83:708-711.

Berkenbosch F, Van Oers J, Del Rey A, Tilders F, Besedovsky H (1987) 
Corticotropin-releasing factor-producing neurons in the rat activated by interleukin-1. Science 238:524-526.

Besedovsky HO, Del Rey A (1996) Immune-neuro-endocrine interactions: facts and hypotheses. Endocr Rev 17:64-102.

Bette M, Schafer MK, Van Rooijen N, Weihe E, Fleischer B (1993) Distribution and kinetics of superantigen-induced cytokine gene expression in mouse spleen. J Exp Med 178:1531-1539.

Brady LS, Lynn AB, Herkenham M, Gottesfeld Z (1994) Systemic interleukin-1 induces early and late patterns of $c$-fos mRNA expression in brain. J Neurosci 14:4951-4964.

Brouxhon SM, Prasad AV, Joseph SA, Felten DL, Bellinger DL (1998) Localization of corticotropin-releasing factor in primary and secondary lymphoid organs of the rat. Brain Behav Immunol 12:107-122.

Buller KM, Xu Y, Day TA (1998) Indomethacin attenuates oxytocin and hypothalamic-pituitary-adrenal axis responses to systemic interleukin$1 \beta$. J Neuroendocrinol 10:519-528.

Connor TJ, Song C, Leonard BE, Merali Z, Anisman H (1998) An assessment of the effects of central interleukin- $1 \beta,-2,-6$, and tumor necrosis factor- $\alpha$ administration on some behavioural, neurochemical, endocrine, and immune parameters in the rat. Neuroscience 84:923-933.

Davis M (1992) The role of the amygdala in fear and anxiety. Annu Rev Neurosci 15:353-375.

Derijk R, Van Rooijen N, Tilders FJ, Besedovsky HO, Del Rey A, Berkenbosch F (1991) Selective depletion of macrophages prevents pituitary-adrenal activation in response to subpyrogenic, but not to pyrogenic, doses of bacterial endotoxin in rats. Endocrinology 129:330-338.

Dunn AJ (1993) Infection as a stressor: a cytokine-mediated activation of the hypothalamo-pituitary-adrenal axis? Ciba Found Symp [Discussion 172:239-242] 172:226-239.

Dunn AJ, Berridge CW (1990) Physiological and behavioral responses to corticotropin-releasing factor administration: is $\mathrm{CRF}$ a mediator of anxiety or stress responses? Brain Res Brain Res Rev 15:71-100.

Dunn AJ, Antoon M, Chapman Y (1991) Reduction of exploratory behavior by intraperitoneal injection of interleukin-1 involves brain corticotrophin-releasing factor. Brain Res Bull 26:539-542.

Exton MS, Bull DF, King MG (1995) Behavioral conditioning of lipopolysaccharide-induced anorexia. Physiol Behav 57:401-405.

Florquin S, Amraoui Z, Abramowicz D, Goldman M (1994) Systemic release and protective role of IL-10 in staphylococcal enterotoxin B-induced shock in mice. J Immunol 153:2618-2623.

Gonzalo JA, Gonzalez-Garcia A, Martinez C, Kroemer G (1993) Glucocorticoid-mediated control of the activation and clonal deletion of peripheral T-cells in vivo. J Exp Med 177:1239-1246.

Gonzalo JA, Baixeras E, Gonzalez-Garcia A, George-Chandy A, Van Rooijen N, Martinez C, Kroemer G (1994) Differential in vivo effects of a superantigen and an antibody targeted to the same T-cell receptor. Activation-induced cell death vs passive macrophage-dependent deletion. J Immunol 152:1597-1608.

Haas HS, Schauenstein K (1997) Neuroimmunomodulation via limbic structures-the neuroanatomy of psychoimmunology. Prog Neurobiol 51:195-222.

Hanisch UK, Quirion R (1995) Interleukin-2 as a neuroregulatory cytokine. Brain Res Brain Res Rev 21:246-284.

Hanisch UK, Rowe W, Sharma S, Meaney MJ, Quirion R (1994) Hypothalamic-pituitary-adrenal activity during chronic central administration of interleukin-2. Endocrinology 135:2465-2472.

Hebb AL, Zacharko RM, Anisman H (1998) Self-stimulation from the mesencephalon following intraventricular interleukin-2 administration. Brain Res Bull 45:549-556.

Heilig M, Koob GF, Ekman R, Britton KT (1994) Corticotropinreleasing factor and neuropeptide $\mathrm{Y}$ : role in emotional integration. Trends Neurosci 17:80-85.

Herman JP, Cullinan WE (1997) Neurocircuitry of stress: central control of the hypothalamo-pituitary-adrenocortical axis. Trends Neurosci 20:78-84.

Hsu DT, Chen FL, Takahashi LK, Kalin NH (1998) Rapid stressinduced elevations in corticotropin-releasing hormone mRNA in rat central amygdala nucleus and hypothalamic paraventricular nucleus —an in situ hybridization analysis. Brain Res 788:305-310.

Imaki T, Xiao-Quan W, Shibasaki T, Yamada K, Harada S, Chikada N, Naruse M, Demura H (1995) Stress-induced activation of neuronal activity and corticotropin-releasing factor gene expression in the para- ventricular nucleus is modulated by glucocorticoids in rats. J Clin Invest 96:231-238.

Janz LJ, Green-Johnson J, Murray L, Vriend CY, Nance DM, Greenberg AH, Dyck DG (1996) Pavlovian conditioning of LPS-induced responses: effects on corticosterone, splenic NE, and IL-2 production. Physiol Behav 59:1103-1109.

Johnson HM, Russell JK, Pontzer CH (1991) Staphylococcal enterotoxin microbial superantigens. FASEB J 5:2706-2712.

Keegan CE, Herman JP, Karolyi IJ, O'Shea KS, Camper SA, Seasholtz AF (1994) Differential expression of corticotropin-releasing hormone in developing mouse embryos and adult brain. Endocrinology 134:2547-2555.

Kelso A, Troutt AB, Maraskovsky E, Gough NM, Morris L, Pech MH, Thomson JA (1991) Heterogeneity in lymphokine profiles of CD4 ${ }^{+}$ and $\mathrm{CD} 8{ }^{+} \mathrm{T}$-cells and clones activated in vivo and in vitro. Immunol Rev 123:85-114.

Kent S, Kelley KW, Dantzer R (1992) Effects of lipopolysaccharide on food-motivated behavior in the rat are not blocked by an interleukin-1 receptor antagonist. Neurosci Lett 145:83-86.

Kotzin BL, Leung DY, Kappler J, Marrack P (1993) Superantigens and their potential role in human disease. Adv Immunol 54:99-166.

Kovacs KJ, Sawchenko PE (1996) Sequence of stress-induced alterations in indices of synaptic and transcriptional activation in parvocellular neurosecretory neurons. J Neurosci 16:262-273.

Lacosta S, Merali Z, Anisman H (1998) Influence of interleukin-1 $\beta$ on exploratory behaviors, plasma ACTH, corticosterone, and central biogenic amines in mice. Psychopharmacology 137:351-361.

Laflamme N, Barden N, Rivest S (1997) Corticotropin-releasing factor and glucocorticoid receptor (GR) gene expression in the paraventricular nucleus of immune-challenged transgenic mice expressing type II GR antisense ribonucleic acid. J Mol Neurosci 8:165-179.

Litton MJ, Sander B, Murphy E, O'Garra A, Abrams JS (1994) Early expression of cytokines in lymph nodes after treatment in vivo with Staphylococcus enterotoxin B. J Immunol Methods 175:47-58.

London CA, Abbas AK, Kelso A (1998) Helper T-cell subsets: heterogeneity, functions, and development. Vet Immunol Immunopathol 63:37-44.

Maes M (1995) Evidence for an immune response in major depression: a review and hypothesis. Prog Neuropsychopharmacol Biol Psychiatry 19:11-38.

Maier SF, Watkins LR (1995) Intracerebroventricular interleukin-1 receptor antagonist blocks the enhancement of fear conditioning and interference with escape produced by inescapable shock. Brain Res 695:279-282.

Maier SF, Watkins LR (1998) Cytokines for psychologists: implications of bidirectional immune-to-brain communication for understanding behavior, mood, and cognition. Psychol Rev 105:83-107.

Marrack P, Winslow GM, Choi Y, Scherer M, Pullen A, White J, Kappler JW (1993) The bacterial and mouse mammary tumor virus superantigens: two different families of proteins with the same functions. Immunol Rev 131:79-92.

Merali Z, McIntosh J, Kent P, Michaud D, Anisman H (1998) Aversive and appetitive events evoke the release of corticotropin-releasing hormone and bombesin-like peptides at the central nucleus of the amygdala. J Neurosci 18:4758-4766.

Miller JA (1991) The calibration of ${ }^{35} \mathrm{~S}$ or ${ }^{32} \mathrm{P}$ with ${ }^{14} \mathrm{C}$-labeled brain paste or ${ }^{14} \mathrm{C}$ plastic standards for quantitative autoradiography using LKB ultrofilm or Amersham hyperfilm. Neurosci Lett 121:211-214.

Montkowski A, Landgraf R, Yassouridis A, Holsboer F, Schobitz B (1997) Central administration of IL-1 reduces anxiety and induces sickness behaviour in rats. Pharmacol Biochem Behav 58:329-336.

Muglia LJ, Jenkins NA, Gilbert DJ, Copeland NG, Majzoub JA (1994) Expression of the mouse corticotropin-releasing hormone gene in vivo and targeted inactivation in embryonic stem cells. J Clin Invest 93:2066-2072.

Owens MJ, Nemeroff CB (1991) Physiology and pharmacology of corticotropin-releasing factor. Pharmacol Rev 43:425-473.

Plata-Salaman CR (1996) Anorexia during acute and chronic disease [see comments; review]. Nutrition 12:69-78.

Raber J, Koob GF, Bloom FE (1995) Interleukin-2 (IL-2) induces corticotropin-releasing factor (CRF) release from the amygdala and involves a nitric oxide-mediated signaling: comparison with the hypothalamic response. J Pharmacol Exp Ther 272:815-824.

Rassnick S, Heinrichs SC, Britton KT, Koob GF (1993) Microinjection 
of a corticotropin-releasing factor antagonist into the central nucleus of the amygdala reverses anxiogenic-like effects of ethanol withdrawal. Brain Res 605:25-32.

Rodriguez dF, Carrera MA, Navarro M, Koob GF, Weiss F (1997) Activation of corticotropin-releasing factor in the limbic system during cannabinoid withdrawal. Science 276:2050-2054.

Sapolsky R, Rivier C, Yamamoto G, Plotsky P, Vale W (1987) Interleukin-1 stimulates the secretion of hypothalamic corticotropinreleasing factor. Science 238:522-524.

Schrott LM, Crnic LS (1996) Increased anxiety behaviors in autoimmune mice. Behav Neurosci 110:492-502.

Schrott LM, Crnic LS (1998) Attenuation of behavioral abnormalities in autoimmune mice by chronic soluble interferon-gamma receptor treatment. Brain Behav Immunol 12:90-106.

Shurin G, Shanks N, Nelson L, Hoffman G, Huang L, Kusnecov AW (1997) Hypothalamic-pituitary-adrenal activation by the bacterial superantigen staphylococcal enterotoxin B: role of macrophages and T-cells. Neuroendocrinology 65:18-28.

Smith GW, Aubry JM, Dellu F, Contarino A, Bilezikjian LM, Gold LH, Chen R, Marchuk Y, Hauser C, Bentley CA, Sawchenko PE, Koob GF, Vale W, Lee KF (1998) Corticotropin releasing factor receptor 1-deficient mice display decreased anxiety, impaired stress response, and aberrant neuroendocrine development. Neuron 20:1093-1102.

Spadaro F, Dunn AJ (1990) Intracerebroventricular administration of interleukin-1 to mice alters investigation of stimuli in a novel environment. Brain Behav Immunol 4:308-322.

Stenzel-Poore MP, Cameron VA, Vaughn J, Sawchenko PE, Vale W
(1992) Development of Cushing's syndrome in corticotropin-releasing factor transgenic mice. Endocrinology 130:3378-3386.

Stout JC, Weiss JM (1994) An animal model for measuring behavioral responses to anxiogenic and anxiolytic manipulations. Pharmacol Biochem Behav 47:459-465.

Troutt AB, Maraskovsky E, Rogers LA, Pech MH, Kelso A (1992) Quantitative analysis of lymphokine expression in vivo and in vitro. Immunol Cell Biol 70:51-57.

Van de Kar LD, Piechowski RA, Rittenhouse PA, Gray TS (1991) Amygdaloid lesions: differential effect on conditioned stress and immobilization-induced increases in corticosterone and renin secretion. Neuroendocrinology 54:89-95.

Walker LG, Wesnes KP, Heys SD, Walker MB, Lolley J, Eremin O (1996) The cognitive effects of recombinant interleukin-2 (rIL-2) therapy: a controlled clinical trial using computerized assessments. Eur J Cancer [A] 32:2275-2283.

Walker LG, Walker MB, Heys SD, Lolley J, Wesnes K, Eremin O (1997) The psychological and psychiatric effects of rIL-2 therapy: a controlled clinical trial. Psychooncology 6:290-301.

Wood AC, Todd I (1995) Staphylococcal enterotoxin B toxicity in BALB/c mice: effect on T-cells, plasma cytokine levels, and biochemical markers. FEMS Immunol Med Microbiol 11:91-97.

Yamamoto T, Shimura T, Sako N, Yasoshima Y, Sakai N (1994) Neural substrates for conditioned taste aversion in the rat. Behav Brain Res 65:123-137.

Zalcman S, Green-Johnson JM, Murray L, Nance DM, Dyck D, Anisman H, Greenberg AH (1994) Cytokine-specific central monoamine alterations induced by interleukin-1, -2 , and -6 . Brain Res 643:40-49. 